\title{
Mucinous Cystadenoma
}

National Cancer Institute

\section{Source}

National Cancer Institute. Mucinous Cystadenoma. NCI Thesaurus. Code C2973.

A benign or low malignant potential cystic epithelial neoplasm composed of cells which contain intracytoplasmic mucin. It may arise from the ovary, pancreas, appendix, and lung. 